\title{
THE PHENOMENON OF "ECOLOGICAL SELF-AWARENESS" AND ITS INFLUENCE ON ECOLOGICAL TOURISM
}

\author{
Valentina NAKONECHNYKH* \\ V.N. Nakonechnykh Irkutsk State University, Department of Advertising, 126 Lermontov, Irkutsk, Russia, e-mail: nvn_60@mail.ru \\ Margarita ZHURAVLEVA \\ M.M. Zhuravleva Irkutsk State University, Department of Mass Communication \\ and MultimediaTechnologies , 126 Lermontov, Irkutsk, Russia, e-mail: margo32@mail.ru
}

Svetlana VOLOKHOVA

S.G. Volokhova Irkutsk State University, Department of Entrepreneurship and Management in Services and Advertising, 126 Lermontov st., 664033, Irkutsk, Russia, e-mail: sve-volokhova@ yandex.ru

\section{Marina VILCHINSKAIA}

M.A. Vilchinskaia Irkutsk State University, Department of Entrepreneurship and Management in Services and Advertising, 126 Lermontov st., 664033, Irkutsk, Russia, e-mail: vil-marina@ yandex.ru

\begin{abstract}
Citation: Nakonechnykh, V.N., Zhuravleva, M.M., Volokhova, S.G., \& Vilchinskaia, M.A. (2021). THE PHENOMENON OF "ECOLOGICAL SELF-AWARENESS" AND ITS INFLUENCE ON ECOLOGICAL TOURISM. GeoJournal of Tourism and Geosites, 37(3), 909-913. https://doi.org/10.30892/gtg.37323-725
\end{abstract}

\begin{abstract}
The concept of "ecological self-awareness" is an integral part of ecological tourism. Ecological tourism is considered in a broad and a narrow aspects. In a broad aspect ecotourism is a market capitalization of the environmental benefits of some regions and the whole country. The Purpose of the research is to detect the influence of ecological self-awareness on the development of ecological tourism. For the first time, from the individual-centered, humanistic, holistic standpoint, the category of ecological self-awareness is defined as complex mental phenomenon, which integrates cognitive, emotional, value and behavioral components, which enhance the attitude of individuals towards ecotourism. The data were collected from the experimental and the control groups by calculating the empirical parameter value. The scale of ranks were used to measure the results. The results show positive changes in ecological self-awareness in the experimental group. The dynamics of the changes in the experimental group is much higher than in the control group. This fact let us assert that the applied formation technology has its effectiveness. The ecological self-awareness is directly related to ecological education and influences the development of ecotourism.
\end{abstract}

Key words: ecological tourism, ecological self-awareness, environment, environmental education, the system of environmental knowledge, skills, attitudes, influence on ecotourism, ecological education

\section{INTRODUCTION}

The concept of "ecological-self-awareness" is an integral part of ecological tourism. Ecological tourism is considered in broad and narrow aspects. In a broad aspect ecotourism is a market capitalization of the environmental benefits of some regions and the whole country. Ecotourism improves socio-economic conditions, increases investment activity of businesses and employment, it also overcomes unemployment by teaching the population specific professional skill, as well as provides the efficient use of the potential of natural recreational facilities and resources and entails the development of transport infrastructure. In a narrow aspect, ecological tourism is associated with recreation and recreational impact on humans. As a one of the popular types of tourism, it is designed to make up for the loss of energy and internal strength due to excessive emotional burnout in the age of information and computer technologies. However, in both aspects the approach to ecological tourism is often just a formality. Despite the reasoning about the recreational effect, which manifests itself as a kind of balance, harmony, calmness, lack of fuss, the connection between these aspects is lost. Ecological self-awareness is the very link between economic needs of a community and tourists' expectations in terms of receiving positive emotions from ecotourism. The Purpose of the research is to detect the influence of ecological self-awareness on the development of ecological tourism.

The scientific novelty of the research is the following. For the first time, from the individual-centered, humanistic, holistic standpoint, the category of ecological self-awareness is defined as complex mental phenomenon, which integrates cognitive, emotional, value and behavioral components, which enhance the attitude of individuals towards ecotourism.

\section{MATERIALS AND METHODS}

The theoretical significance of the study lies in the discovery of the devices, which would stimulate the development of

\footnotetext{
${ }^{*}$ Corresponding author
} 
the ecological self-awareness and the factors which determine their effective impact on ecotourism (Björk, 2000; Blamey, 1997; Cater, 2006; Fenell, 2001). The practical significance of the study lies in the fact that the proposed diagnostic technique allows to indentify the level of ecological self-awareness of an individual and to trace its formation dynamics.

Today, when ecotourism plays a significant part in global tourism industry, special attention should be paid to the prospects for its development in Russian regions. World Tourism Organization (UNWTO) predicts the growth of ecological tourism and its income in the XXI century, which can make a considerable contribution to the development of the Russian economy, especially in developing regions.

Ecotourism, as a rule, implies traveling to places of natural or ecological interest in order to observe wildlife and get an idea of the environmental, cultural and ethnographic features of an area, which do not violate the integrity of ecological systems. From a scientific point of view, such type of tourism contributes to the environmental protection and minimizes the negative impact on it (Collins English Dictionary, 2000). Ecotourism not only stimulates and satisfies the desire to communicate with nature, it is also an important part of the sustainable development of natural areas (Carvache-Franco et al., 2020a; Carvache-Franco et al., 2020b; Eshun, 2020; Fennell, 2004). Moreover, those types of tourism activities that have the most positive environmental, economic and social impact are more sustainable. An integral part of ecotourism is ecological awareness (Szente et al., 2021). Ecological awareness as a reflection of ecological reality and the personal recognition of this reality forms individual ecological self-awareness.

The process of such recognition takes place during environmental education. Environmental education is, first of all, a process of acquisition by a person of his own image in the environment (Sergeeva, 2004). It is makingconditions for the harmonious development of an individual in interaction with nature on the basis of the principles of ecocentrism, and the transformation of a person as a passive observer into an active explorer of environmental issues and a creator of his own sustainable future. Environmental education based only on the traditional knowledge-centered approach cannot provide a solution to ecological problems of current interest, because a person who has mastered the necessary knowledge does not obligatory manifest himself as a subject of ecotourism.

Being both an object and a subject of activity, an individual is transforming not only his bio-social reality, but also himself (Genovese, 2003; Piaget, 1971; Weaver, 2007). In our research we drew on studies of the authors who considered the current problems of the theory and practice of education in the field of the environment and other diverse areas of the humanities: philosophy and global problems of ecology (Weaver, 2005). The works of contemporary authors were of particular interest (Carvache-Franco et al., 2020; Eshun et al., 2020; Higham et al., 2003; Sergeeva, 2004; Szente et al., 2021; Toassa, 2019; Weaver et al., 2007; Zielinski et al., 2020). These authors consider a wide range of issues that can be important for the scientific foundation of phenomenon of eco tourism (Carvache-Franco et al., 2020; Eshun et al., 2020; Higham et al., 2003; Sergeeva, 2004; Szente et al., 2021; Toassa,2019; Weaver et al., 2007; Zielinski et al., 2020).

Environmental education is focused not only on its content, but also on technology. Consequently, the problem of finding means and techniques to stimulate the development of ecological self-awareness becomes urgent (Weaver, 2005). Also the growth of ecotourism in the world has eventually predetermined the formation of ecological selfawareness of people (Toassa, 2019). Ecological self-awareness of an individual has a complex structure and includes the following components (Sergeeva, 2004):

the cognitive component of ecological self-awareness (self-knowledge) characterizes: an individual's awareness of his knowledge / ignorance about natural environment, the interaction between man and nature; knowledge of the behavioral norms and rules of interrelation with nature in accordance with environmental ethics; knowledge on ecology and nature preservation, about the interaction between society and nature; knowledge about himself, induced into selfimage, an emotional view of himself: awareness of the grounds for his participation in environmental protection activities, motivation to learn environmental challenges; the present-self and the future-self of an individual in the interrelations with nature (Wight, 1993);

- the affective component (self-attitude) includes conscientious, emotionally positive attitude and cognitive interest of an individual towards environment; the evaluation of one's actions and the interpersonal relationships with other individuals in the field of environmental preservation; attitude to one's personal qualities and to one's personality as a whole; the assessment of accordance of the present-self to the ideal-self as a subject of ecological activity;

the executive component of ecological self-awareness reflects the behavioral volitional aspect (self-regulation)and includes the ability to see the beauty in nature, enjoy its sounds, colors, aromas, preserve them as a source of joy, the ability to comprehend environmental phenomena, to discover connections and dependencies that exist in the world of plants and animals; draw generalizations and conclusions about the state of environment, make recommendations for a reasonable interaction with it; the ability to protect nature in community-development activities; the skills to regulate the behavior in environment - to define the purpose of the activity, to analyze and to identify conditions, to choose the best technic and sequence of actions, to evaluate the results and to correct them if necessary; the capabilities for personal growth and selffulfillment through participation in ecological activities (Zielinski et al., 2020).

Thus, the ecological self-awareness of an individual is considered as a integral relatively stable structure which involves the individual's ideas about himself as an eco-social being, as a subject of environmental activities in general social ecological system; as a means of resolving the ecological issues on the basis of educated judgments, humanistic ideals and progressive national traditions with a combination of emotional value attitude towards the world around and adequate selfimage (Higham et al., 2003). An abstract society with a whole complex of technocratic and civilization disturbances dominating over it can not be regarded as measure of ecological problems, but a real person who makes decisions and choices in his life. That is why, the environment should gain personally significant meaning for individuals. This will 
revitalize their approach to ecological tourism. To reach that goal it is essential to use forms, methods and means of teaching, where interaction between nature and people should be regarded as interpersonal. Trainings, role plays, media and other practice-oriented and learner-centered techniques to form ecological awareness at school (Higham et al., 2003).

The link between ecological self-awareness and ecotourism is established under the following condition: knowledge on natural and social science should be connected to sensory perception of environment, which awakens aesthetic emotions and generates the desire to make a practical contribution to its improvement. Thus, the core connection between ecological self-awareness and ecotourism is represented by the following knowledge, skills and value attitudes:

- the information about environment, from bio-ecology, human ecology and social ecology, selected and adapted if necessary, about general principles of human behavior in the natural environment, about cause -and- effect dependency between a society and the environment, which helps to find environmental problems solutions and to make right moral choices and decisions;

- concern for natural environment: responsible, careful and empathic attitude to environment, aesthetic experiencing natural areas, the feeling of engagement with native nature;

- skills: the ability to see the beauty in nature, enjoy its sounds, colors, aromas, preserve them as a source of joy, to behave in the natural environment, to comprehend environmental phenomena, to discover connections and dependencies that exist in the world of plants and animals; to draw generalizations and conclusions about the state of nature, to make recommendations for reasonable interaction with it, the ability to protect nature in community-development activities.

Considering that the scale of ranks was used in our research to evaluate the experimental data, it is most expedient to use X2 (chi-squared test)

The empirical parameter value is calculated by following formula (Sergeeva, 2004):

$\Sigma 2=\mathrm{N} * \mathrm{M} * \chi$

Where:

$\mathrm{N}, \mathrm{M}$ - the number of participants in groups;

L -the number of points on the scale of rank. In our case, L = 3 ("low", "medium", "high");

$\mathrm{ni}, \mathrm{mi}$ - the number of participants in groups who received an i-point.

In our case:

$\mathrm{n} 1, \mathrm{~m} 1$ - the number of participants who received a "low score";

$\mathrm{n} 2, \mathrm{~m} 2$ - the number of participants who received an "average score";

n3, m3 - the number of participants who received a "high score";

The empirical parameter value calculated by the formula is compared with critical parameter value (error probability) taken from the table. We have taken the following critical parameter value:

error probability @=0.05. It is usually applied in pedagogical research, the calculations are based on assumptions of no more than $5 \%$ of error probability.

for $\mathrm{L}-1=2$.

In our case critical parameter value is $\mathrm{X} 20.05=5.99$, so we proceed from the fact that if the calculated empirical parameter value in the compared groups:

- less than 5.99 or equal to 5.99, the null hypothesis is accepted and we conclude that the characteristics of the compared groups coincide with the significance level of 0.05 ;

- more than 5.99, the alternative hypothesis is accepted and we conclude that the characteristics of the compared groups are different with a reliability of $95 \%$.

\section{RESULTS AND DISCUSSIONS}

The experiment was carried out to study the level of ecological self-awareness. It was a field experiment conducted among students during their practical training. For the purpose of the experiment a control group and an experimental group of 25 people each were formed. To obtain the necessary date the following methods were applied: observation, interview, archival research. The data required for calculating the empirical parameter value are given below in tables 1, 2, 3 and 4 .

Table 1. Empirical value $\chi 2$ for affective value component (Source: the authors'own calculations)

\begin{tabular}{|l|c|c|c|c|}
\hline & $\begin{array}{c}\text { Experimental group } \\
\text { before the experiment }\end{array}$ & $\begin{array}{c}\text { Experimental group } \\
\text { after the experiment }\end{array}$ & $\begin{array}{c}\text { Control group before } \\
\text { the experiment }\end{array}$ & $\begin{array}{c}\text { Control group after the } \\
\text { experiment }\end{array}$ \\
\hline Experimental group before the experiment & 0 & 21.32 & 0.35 & 2.04 \\
\hline Experimental group after the experiment & 21.32 & 0 & 20.16 & 14.48 \\
\hline Control group before the experiment & 0.35 & 20.16 & 0 & 1.11 \\
\hline Control group after the experiment & 2.04 & 14.48 & 1.11 & 0 \\
\hline
\end{tabular}

Table 2. Empirical value 2 for cognitive component (Source: the authors'own calculations)

\begin{tabular}{|l|c|c|c|c|}
\hline & $\begin{array}{c}\text { Experimental group } \\
\text { before the experiment }\end{array}$ & $\begin{array}{c}\text { Experimental group } \\
\text { after the experiment }\end{array}$ & $\begin{array}{c}\text { Control group before } \\
\text { the experiment }\end{array}$ & $\begin{array}{c}\text { Control group after } \\
\text { the experiment }\end{array}$ \\
\hline Experimental group before the experiment & 0 & 21.46 & 0.35 & 2.01 \\
\hline Experimental group after the experiment & 21.46 & 0 & 16.95 & 13.2 \\
\hline Control group before the experiment & 0.35 & 16.95 & 0 & 1.59 \\
\hline Control group after the experiment & 2.01 & 13.2 & 1.59 & 0 \\
\hline
\end{tabular}


Table 3. Empirical value $\chi 2$ for executive component (Source: the authors 'own calculations)

\begin{tabular}{|l|c|c|c|c|}
\hline & \multicolumn{5}{|c|}{$\begin{array}{c}\text { Experimental group } \\
\text { before the experiment }\end{array}$} & $\begin{array}{c}\text { Experimental group } \\
\text { after the experiment }\end{array}$ & $\begin{array}{c}\text { Control group before } \\
\text { the experiment }\end{array}$ & $\begin{array}{c}\text { Control group after } \\
\text { the experiment }\end{array}$ \\
\hline Experimental group before the experiment & 0 & 21.35 & 1.4 & 1.95 \\
\hline Experimental group after the experiment & 21.35 & 0 & 13.44 & 12.44 \\
\hline Control group before the experiment & 1.4 & 13.44 & 0 & 0.04 \\
\hline Control group after the experiment & 1.95 & 12.44 & 0.04 & 0 \\
\hline
\end{tabular}

Table 4. Empirical value $\chi 2$ for the level of ecological self-awareness (Source: the authors 'own calculations)

\begin{tabular}{|l|c|c|c|c|}
\hline & $\begin{array}{c}\text { Experimental group } \\
\text { before the experiment }\end{array}$ & $\begin{array}{c}\text { Experimental group } \\
\text { after the experiment }\end{array}$ & $\begin{array}{c}\text { Control group before } \\
\text { the experiment }\end{array}$ & $\begin{array}{c}\text { Control group } \\
\text { aftertheexperiment }\end{array}$ \\
\hline Experimental group before the experiment & 0 & 25.02 & 0.48 & 1.61 \\
\hline Experimental group after the experiment & 25.02 & 0 & 19.94 & 15.39 \\
\hline Control group before the experiment & 0.48 & 19.94 & 0 & 0.71 \\
\hline Control group after the experiment & 1.61 & 15.39 & 0.71 & 0 \\
\hline
\end{tabular}

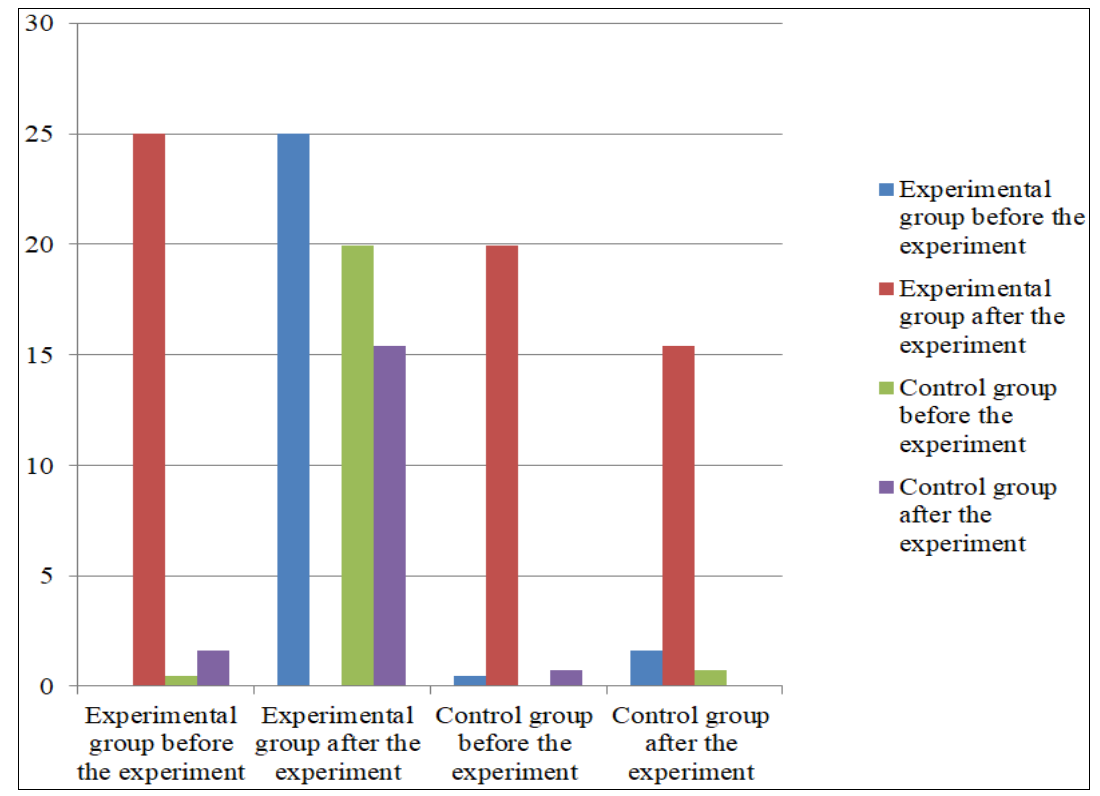

Figure 1. Empirical value parameter for the level of ecological self-awareness (Source: developed by the authors)
During the research the following indicators of the level of the ecological self-awareness were identified: cognitive, affective, executive. The evaluation criteria for affective component were the following indicators (Figure 1):

- enhanced appreciation of natural environment: aesthetic experiencing natural areas, demonstration of responsible and respectful approach towards nature;

- attitude to one's personality as a subject of environmental activity, cognitive interest in acquiring the norms of ecological tourism.

The evaluation criteria for the cognitive component were:

- the knowledge of ecological issues, the interaction between a society and various natural systems;

- the knowledge about oneself as a subject of environment protection activity.

The evaluation criteria for the behavioral component were:

- showing conservation initiative in the immediate environment;

- pro-environmental skills, regarding living and non living nature as a subject;

- self-reflection, self-esteem and self-regulation in the ecological environment.

At the initial stage a low level of ecological awareness was testified both in the experimental and the control groups, which, in turn, indicates a low impact on the attitude of the participants towards ecotourism. The projective technology was applied and its effectiveness was proved. Thus, the dynamics of the ecological self-awareness formation in percentage terms for all the above components were significantly higher in the experimental group than in the control group. Based on the results represented in the tables we can conclude: empirical parameter value X2 for experimental group compared with control group (including classes) before the experiment is less than 5.99, which means null hypothesis is not rejected and it can be claimed that the level of ecological self-awareness in both groups coincides at the initial stage. Moreover, the empirical parameter value X2 for experimental group after the completion of the experiment, compared with control group (including classes) is more than 5.99, which means the alternative hypothesis is confirmed and it can be concluded that the characteristics of the compared groups differ with $95 \%$ reliability. The empirical parameter value X2, calculated for control group after the completion of the experiment, compared to experimental and control groups before the experiment (including classes) is less than 5.99, which means null hypothesis is not rejected and it can be claimed that the characteristics of the compared groups coincide with a significance level of 0.05 .

Therefore, the analysis of the experiment's results shows the changes in the level of ecological self awareness of the research participants, which revitalizes their attitude towards ecological tourism.

\section{CONCLUSION}

The development of ecotourism as an industry is impossible without potential tourists having a steady interest in this type of recreation. This interest underlines the formation of a positive and meaningful attitude towards ecotourism. Such an 
attitude is established through enhancing the ecological self-awareness of an individual. Ecological self-awareness is an integrative personal structure, which combines knowledge about oneself and an emotional attitude to one's personality as a part of ecological activity and self-regulation in a specified activity. All three components are purposefully developed in dialectical unity, according to the age and the individual characteristics of a person. The enhancing of ecological selfawareness of an individual is a process of stimulating his personal self-growth and sensitivity to natural environment. This process is qualified by following criteria: the need for related, concerned, careful experiencing the natural environment and its inhabitants; the assimilation of the norms of environmentally sound interaction with living and non living matter and the focus on their practical application; the manifestation of the initiative to improve the quality of the immediate environment.

According to the result of the experiment we can conclude that projective technology, applied in the experimental group, occurred positive changes in the ecological self-awareness of the participants. This tendency is revealed in all components and let us assume that the formation technology has shown its effectiveness and will enrich the ecological education. Representation of these two concepts in every civilian's life can help them to obtain the feeling of the harmony with natural environment and a sense of security in the areas where ecological tourism is carried out.

\section{REFERENCES}

Björk, P. (2000). Ecotourism from a conceptual perspective, an extended definition of a unique tourism form. International Journal of Tourism Research, 2, 189-202. https://doi.org/10.1002/(SICI)1522-1970(200005/06)2:33.3.CO;2-K

Blamey, R. (1997). Ecotourism: the search for an operational definition. Journal of Sustainable Tourism, 5(2), 109-130. https://doi.org/10.1080/09669589708667280

Cater, E. (2006). Ecotourism as a Western Construct.Journal of Ecotourism, 5(1-2), 23-39. https://doi: 10.1080/14724040608668445

Carvache-Franco, M., Carvache-Franco, O., Carvache-Franco, W., \& Villagómez-Buele, C. (2020). From Satisfaction in Eco-Tourism to Loyalty in a National Park. GeoJournal of Tourism and Geosites, 28(1), 191-202. https://doi.org/10.30892/gtg.28115-462

Eshun, G., \& Tichaawa, T.M. (2020). Community Participation, Risk Management and Ecotourism Sustainability Issues in Ghana. GeoJournal of Tourism and Geosites, 28(1), 313-331. https://doi.org/10.30892/gtg.28125-472

Carvache-Franco, M., Carvache-Franco, O., Carvache-Franco, W., Villagómez-Buele, C., \& Saltos-Layana, A. (2020). Sociodemographic aspects and their relationship with the Ecotourists' motivations in a Coastal national Park from Ecuador. GeoJournal of Tourism and Geosites, 31(3), 1075-1082. https://doi.org/10.30892/gtg.31320-543

Fennell, D.A. (2001). A Content Analysis of Ecotourism Definitions. Current Issues in Tourism, 4(5), 403-421. https://doi: $10.1080 / 13683500108667896$

Fennell, D., \& Ebert, K. (2004). Tourism and the precautionary principle. Journal of Sustainable Tourism, 12(6), 461-479. https://doi: $10.1080 / 09669580408667249$

Toassa, G. (2019). Leontiev about Matter and Consciousness: His Critique of Vygotsky in the Soviet context. Psicologia: Teoria e Pesquisa, 35, Brasília. https://doi:10.1590/0102.3772e35315

Higham, J.E.S., \& Carr, A. (2003). Defining ecotourism in New Zealand: differentiating between the defining parameters within a national/regional context. Journal of Ecotourism, 2(1), 17-32. https://doi: 10.1080/14724040308668131

Genovese, J.E.C. (2003). Piaget, Pedagogy, and Evolutionary Psychology. Evolutionary Psychology, 1(1), 127-137. https://doi: $10.1177 / 147470490300100109$

Szente, V., Osiako, P.O., Nagy, M.Z., Pintér, A., \& Szigeti, O. (2021). Community based Ecotourism in Hungary: Citizens perceptions towards the roma community. GeoJournal of Tourism and Geosites, 34(1), 233-239. https://doi.org/10.30892/gtg.34131-642

Weaver, D.B., \& Lawton, L.J. (2007). Twenty years on: The state of contemporary ecotourism research. Tourism Management, 28(5), 1168-1179. https://doi: 10.1016/j.tourman.2007.03.004

Weaver, D.B. (2005). Mass and Urban Ecotourism: New Manifestions of an Old Concept. Tourism Recreation Research, 30(1), 19-26. https://doi: 10.1080/02508281.2005.11081230

Wight, P.A. (1993). Ecotourism: Ethics or Eco-sell? Journal of Travel Research, 31(3), 3-9. https://doi: 10.1177/004728759303100301

Zielinski, S., Jeong, Y., \& Milanés, C.B. (2020). Factors that influence community-based tourism (CBT) in developing and developed countries. Tourism Geographies, 1-33. https://doi.org/10.1080/14616688.2020.1786156

Piaget, J. (1969). Избранные психологические труды [Selected psychological works], Moscow, Russia.

Sergeeva, T.K. (2004). Ecological tourism. The textbook on Tourism Management, Moscow, Finance and Statistics, 358, ISBN 5-27902819-3, 5000, ( Russia).

*** Collins Dictionaries (2018). Collins English Dictionary Complete and Unabridged. 13th Revised Edition, Collins, 2336.

Article history: Received: 12.02.2021 Revised: 06.06.2021 Accepted: 31.08.2021 Available online: 21.09.2021 